\title{
Patulin-Induced Suicidal Erythrocyte Death
}

\author{
Adrian Lupescu Kashif Jilani Mohanad Zbidah Florian Lang \\ Department of Physiology, University of Tuebingen, Tuebingen, Germany
}

\section{Key Words}

Phosphatidylserine $\cdot$ Patulin $•$ Calcium $•$ Cell volume $・$ Eryptosis

\begin{abstract}
Background: Patulin, the most common mycotoxin in apples and apple-derived products, triggers apoptosis and has thus been considered for the treatment of cancer. Similar to apoptosis of nucleated cells, erythrocytes may enter suicidal death or eryptosis, which is characterized by cell shrinkage and by cell membrane scrambling leading to phosphatidylserine-exposure at the erythrocyte surface. Stimulators of eryptosis include increase of cytosolic $\mathrm{Ca}^{2+}$-activity $\left(\left[\mathrm{Ca}^{2+}\right]_{\mathrm{i}}\right)$. The present study explored, whether exposure of human erythrocytes to patulin is followed by eryptosis. Methods: Forward scatter was measured to estimate cell volume, annexin $\mathrm{V}$ binding to detect phosphatidylserine-exposure, hemoglobin release to quantify hemolysis, and Fluo3-fluorescence to determine $\left[\mathrm{Ca}^{2+}\right]_{i}$. Results: A $48 \mathrm{~h}$ exposure to patulin significantly increased $\left[\mathrm{Ca}^{2+}\right]_{\mathrm{I}}(5 \mu \mathrm{M})$, significantly decreased forward scatter $(5 \mu \mathrm{M})$ and significantly increased annexin-V-binding $(2.5 \mu \mathrm{M})$. Patulin $(10 \mu \mathrm{M})$ induced annexin-V-binding was virtually abrogated by removal of extracellular $\mathrm{Ca}^{2+}$. Conclusion: Patulin stimulates $\mathrm{Ca}^{2+}$ entry into erythrocytes, an effect triggering suicidal erythrocyte death or eryptosis.
\end{abstract}

Copyright (C) 2013 S. Karger AG, Basel

\section{Introduction}

Patulin, a genotoxic mycotoxin produced by several species of Aspergillus, Penicillium and Byssochlamys [1,2], is the most common mycotoxin in apples and apple-derived products [2]. It contaminates further fruits, such as grapes, oranges, pears and peaches $[1,3]$. Cellular effects of patulin include formation of reactive oxygen species (ROS), cell cycle arrest, cytochrome c release from mitochondria, caspase-3 activation, PARP cleavage, ATF3 expression and subsequent apoptosis [1, 3-6]. Patulin causes DNA damage and is mutagenic, carcinogenic and teratogenic $[1,3]$. On the other hand, in view of its ability to 
trigger apoptosis of tumor cells, patulin has been considered a candidate for the treatment of malignancy $[4,5]$.

Erythrocytes lack mitochondria and nuclei and cannot experience mitochondrial cytochrome c release and DNA fragmentation, hallmarks of apoptosis [7]. Nevertheless, erythrocytes may experience apoptosis-like suicidal death or eryptosis, which is characterized by cell membrane scrambling and cell shrinkage [7]. Eryptosis may be triggered by increase of cytosolic $\mathrm{Ca}^{2+}$ concentration $\left(\left[\mathrm{Ca}^{2+}\right]_{\mathrm{i}}\right)$ following $\mathrm{Ca}^{2+}$ entry through $\mathrm{Ca}^{2+}$-permeable cation channels [8,9]. The channels are activated by oxidative stress [10]. Increased $\left[\mathrm{Ca}^{2+}\right]_{\mathrm{i}}$ activates $\mathrm{Ca}^{2+}$-sensitive $\mathrm{K}^{+}$channels [11] leading to cell shrinkage due to $\mathrm{K}^{+}$ exit, hyperpolarization, $\mathrm{Cl}^{-}$exit and thus cellular $\mathrm{KCl}$ and water loss [12]. Increased $\left[\mathrm{Ca}^{2+}\right]_{\mathrm{i}}$ further triggers cell membrane scrambling with subsequent phosphatidylserine exposure at the erythrocyte surface [13]. The $\mathrm{Ca}^{2+}$ sensitivity of eryptosis is enhanced by ceramide [14]. Moreover, eryptosis is triggered by energy depletion [15], caspase activation [16-20], and deranged activity of distinct kinases, such as AMP activated kinase AMPK [9], cGMPdependent protein kinase [21] or Janus-activated kinase JAK3 [22].

Eryptosis is stimulated by a wide variety of xenobiotics including several food contaminants [16, 22-25, 25-36]. Moreover, eryptosis is observed in several clinical disorders [7], such as diabetes [20,37, 38], renal insufficiency [39], hemolytic uremic syndrome [40], sepsis [41], sickle cell disease [42], malaria [43-47], Wilson's disease [47], iron deficiency [48], phosphate depletion [49], and presumably metabolic syndrome [50].

The present study elucidated the effect of patulin on $\left[\mathrm{Ca}^{2+}\right]_{\mathrm{i}}$, cell volume and phosphatidylserine abundance at the erythrocyte surface. The results indicate that patulin is a powerful stimulator of eryptosis.

\section{Materials and Methods}

\section{Erythrocytes, solutions and chemicals}

Leukocyte-depleted erythrocytes were kindly provided by the blood bank of the University of Tübingen. The study is approved by the ethics committee of the University of Tübingen $(184 / 2003 V)$. Erythrocytes were incubated in vitro at a hematocrit of $0.4 \%$ in Ringer solution containing (in mM) $125 \mathrm{NaCl}, 5 \mathrm{KCl}, 1 \mathrm{MgSO}_{4}$, $32 \mathrm{~N}$-2-hydroxyethylpiperazine-N-2-ethanesulfonic acid (HEPES), 5 glucose, $1 \mathrm{CaCl}_{2} ; \mathrm{pH} 7.4$ at $37^{\circ} \mathrm{C}$ for $48 \mathrm{~h}$. Where indicated, erythrocytes were exposed to patulin (Enzo, Lörrach, Germany) at the indicated concentrations. In $\mathrm{Ca}^{2+}$-free Ringer solution, $1 \mathrm{mM} \mathrm{CaCl}_{2}$ was substituted by $1 \mathrm{mM}$ glycol-bis(2-aminoethylether)-N,N,N',N'tetraacetic acid (EGTA).

\section{FACS analysis of annexin-V-binding and forward scatter}

After incubation under the respective experimental condition, $50 \mu \mathrm{l}$ cell suspension was washed in Ringer solution containing $5 \mathrm{mM} \mathrm{CaCl}_{2}$ and then stained with Annexin-V-FITC (1:200 dilution; ImmunoTools, Friesoythe, Germany) in this solution at $37^{\circ} \mathrm{C}$ for 20 min under protection from light. In the following, the forward scatter (FSC) of the cells was determined, and annexin-V fluorescence intensity was measured in FL-1 with an excitation wavelength of $488 \mathrm{~nm}$ and an emission wavelength of $530 \mathrm{~nm}$ on a FACS Calibur (BD, Heidelberg, Germany).

\section{Measurement of intracellular $\mathrm{Ca}^{2+}$}

After incubation erythrocytes were washed in Ringer solution and then loaded with Fluo-3/AM (Biotium, Hayward, USA) in Ringer solution containing $5 \mathrm{mM} \mathrm{CaCl}_{2}$ and $2 \mu \mathrm{M}$ Fluo-3/AM. The cells were incubated at $37^{\circ} \mathrm{C}$ for $30 \mathrm{~min}$ and washed twice in Ringer solution containing $5 \mathrm{mM} \mathrm{CaCl}$. The Fluo-3/AMloaded erythrocytes were resuspended in $200 \mu \mathrm{l}$ Ringer. Then, $\mathrm{Ca}^{2+}$-dependent fluorescence intensity was measured in fluorescence channel FL-1 in FACS analysis.

\section{Measurement of hemolysis}

For the determination of hemolysis the samples were centrifuged ( $3 \mathrm{~min}$ at $400 \mathrm{~g}$, room temperature) after incubation, and the supernatants were harvested. As a measure of hemolysis, the hemoglobin ( $\mathrm{Hb})$ 
A

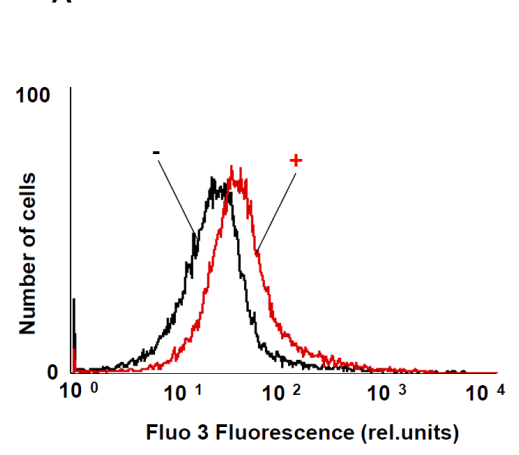

B

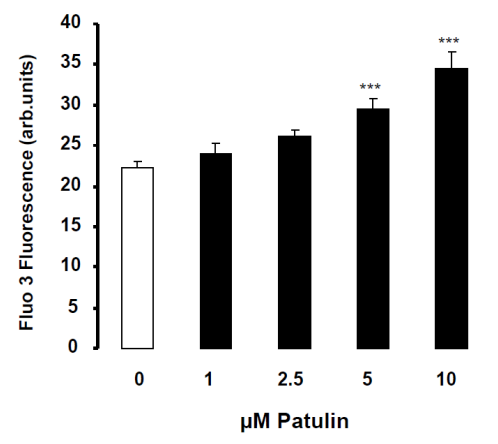

Fig. 1. Effect of patulin on erythrocyte cytosolic $\mathrm{Ca}^{2+}$ concentration. A. Original histogram of Fluo3 fluorescence in erythrocytes following exposure for $48 \mathrm{~h}$ to Ringer solution without (-) and with (+) presence of $10 \mu \mathrm{M}$ patulin. B. Arithmetic means \pm SEM $(n=12)$ of the Fluo3 fluorescence (arbitrary units) in erythrocytes exposed for $48 \mathrm{~h}$ to Ringer solution without (white bar) or with (black bars) patulin (1-10 $\mu \mathrm{M}$ ). *** $(\mathrm{p}<0.001)$ indicates significant difference from the absence of patulin (ANOVA).

concentration of the supernatant was determined photometrically at $405 \mathrm{~nm}$. The absorption of the supernatant of erythrocytes lysed in distilled water was defined as $100 \%$ hemolysis.

\section{Statistics}

Following flow cytometry, the average of $10^{4}$ cells has been calculated for each erythrocyte preparation. The arithmetic mean \pm the standard error of the mean (SEM) has been calculated from the averaged values obtaind from the different erythrocyte preparations. As indicated in the figure legends, statistical analysis was made using ANOVA with Tukey's test as post-test and $t$ test as appropriate. $\mathrm{n}$ denotes the number of different erythrocyte specimens studied. Since different erythrocyte specimens used in distinct experiments are differently susceptible to triggers of eryptosis, the same erythrocyte specimens have been used for control and experimental conditions.

\section{Results}

In order to explore, whether patulin exposure influences the cytosolic $\mathrm{Ca}^{2+}$ activity $\left(\left[\mathrm{Ca}^{2+}\right]_{\mathrm{i}}\right)$ of human erythrocytes, the erythrocytes were loaded with Fluo3-AM and the Fluo3 fluorescence determined in FACS analysis. Prior to determination of Fluo3-fluorescence the erythrocytes were incubated in Ringer solution without or with patulin (1-10 $\mu \mathrm{M})$. As shown in Fig. 1, a 48 hours exposure of human erythrocytes to patulin was followed by an increase of Fluo3 fluorescence, an effect reaching statistical significance at $5 \mu \mathrm{M}$ patulin concentration. Accordingly, exposure to patulin resulted in an increase of cytosolic $\mathrm{Ca}^{2+}$ concentration.

An increase of $\left[\mathrm{Ca}^{2+}\right]_{\mathrm{i}}$ is known to activate $\mathrm{Ca}^{2+}$-sensitive $\mathrm{K}^{+}$channels leading to cell shrinkage due to $\mathrm{KCl}$ exit paralleled by osmotically obliged water. In order to estimate cell volume, forward scatter was determined in FACS analysis. As shown in Fig. 2, a 48 hours exposure to patulin was followed by a decrease of forward scatter, an effect reaching statistical significance at $5 \mu \mathrm{M}$ patulin. Accordingly, patulin exposure resulted in erythrocyte shrinkage.

An increase of $\left[\mathrm{Ca}^{2+}\right]_{\mathrm{i}}$ is further known to stimulate cell membrane scrambling with loss of lipid asymmetry and eventual phosphatidylserine exposure at the cell surface. To identify phosphatidylserine exposing erythrocytes annexin-V-binding was determined in FACS analysis. As illustrated in Fig. 3, a $48 \mathrm{~h}$ exposure to patulin increased the percentage of annexin-V-binding erythrocytes, an effect reaching statistical significance at $2.5 \mu \mathrm{M}$ 
A

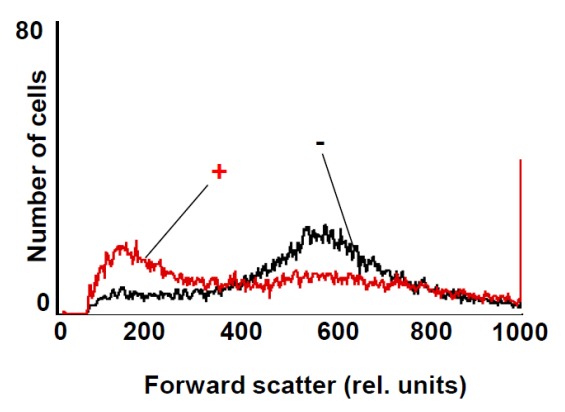

B

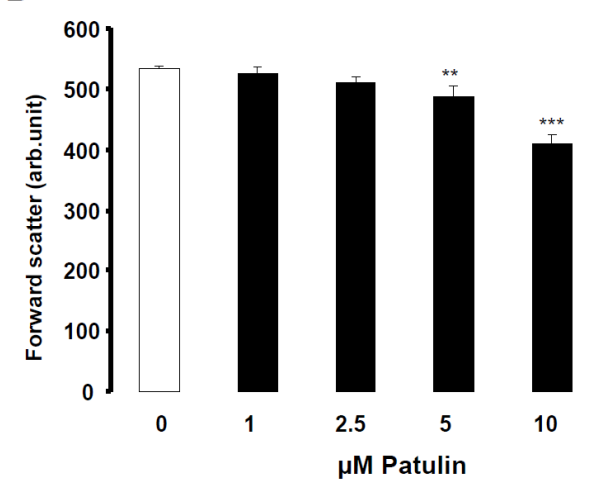

Fig. 2. Effect of patulin on erythrocyte forward scatter. A. Original histogram of forward scatter of erythrocytes following exposure for $48 \mathrm{~h}$ to Ringer solution without (-) and with (+) presence of $10 \mu \mathrm{M}$ patulin. B. Arithmetic means \pm SEM $(n=12)$ of the normalized erythrocyte forward scatter (FSC) following incubation for $48 \mathrm{~h}$ to Ringer solution without (white bar) or with (black bars) patulin $(1-10 \mu \mathrm{M}) .{ }^{* *}(\mathrm{p}<0.01)$, ${ }^{* * *}(\mathrm{p}<0.001)$ indicate significant difference from the absence of patulin (ANOVA).

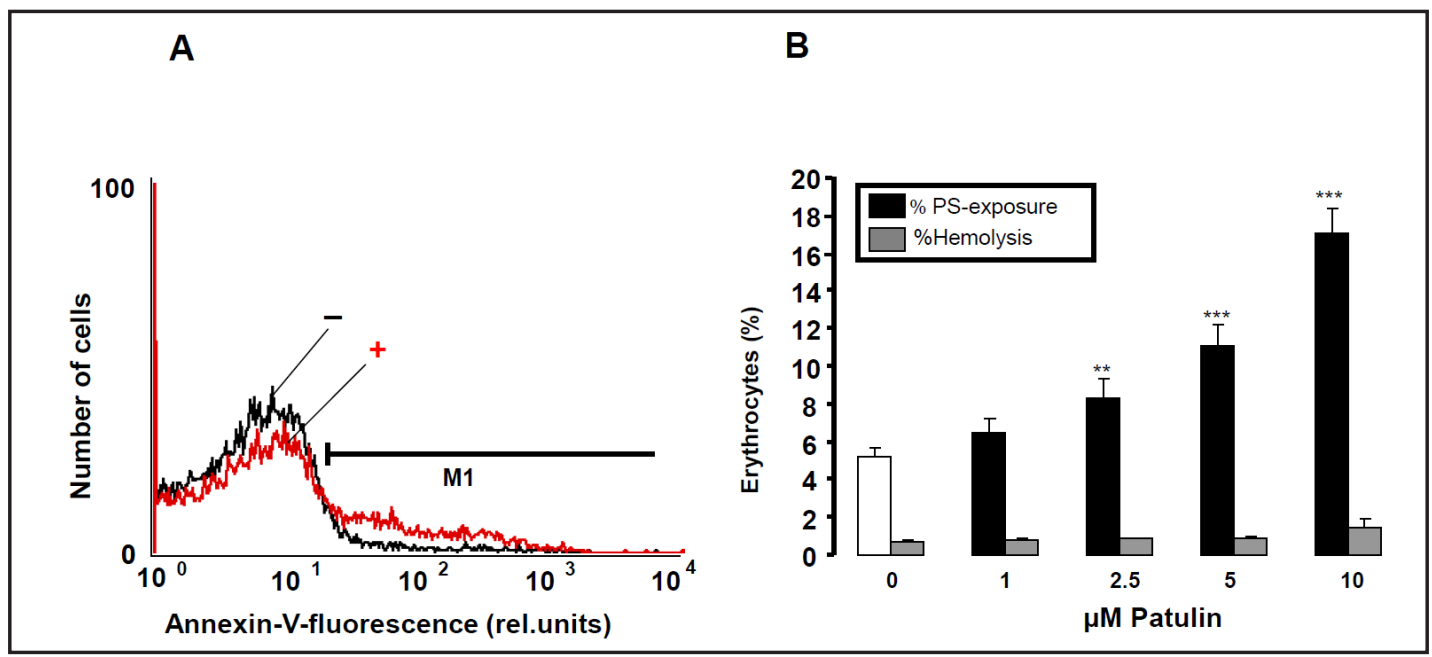

Fig. 3. Effect of patulin on phosphatidylserine exposure and hemolysis. A. Original histogram of annexin- $V$ binding of erythrocytes following exposure for $48 \mathrm{~h}$ to Ringer solution without (-) and with (+) presence of $10 \mu \mathrm{M}$ patulin. B. Arithmetic means \pm SEM of erythrocyte annexin-V-binding $(\mathrm{n}=12)$ following incubation for $48 \mathrm{~h}$ to Ringer solution without (white bar) or with (black bars) presence of patulin (1-10 $\mu \mathrm{M})$. For comparison, arithmetic means \pm SEM $(\mathrm{n}=4)$ of the percentage of hemolysis is shown as grey bars. ${ }^{* *}$ $(\mathrm{p}<0.01),{ }^{* * *}(\mathrm{p}<0.001)$ indicates significant difference from the absence of patulin (ANOVA).

patulin. Accordingly, patulin triggered erythrocyte cell membrane scrambling with phosphatidylserine exposure at the cell surface.

In order to elucidate, whether patulin exposure causes hemolysis, the percentage of hemolysed erythrocytes was estimated from hemoglobin release into the supernatant. As shown in Fig. 3, exposure of erythrocytes for $48 \mathrm{~h}$ to patulin increased the hemoglobin concentration in the supernatant, an effect, however, not reaching statistical significance up to $10 \mu \mathrm{M}$ patulin (Fig. $3 \mathrm{~B}$ )

In order to test, whether the patulin induced increase of $\left[\mathrm{Ca}^{2+}\right]_{\mathrm{i}}$ indeed contributed to or even accounted for the stimulation of patulin induced cell membrane scrambling, erythrocytes were exposed to $10 \mu \mathrm{M}$ patulin for 48 hours in the presence and in the nominal 
Fig. 4. Effect of $\mathrm{Ca}^{2+}$ withdrawal on patulininduced annexin-V-binding. Arithmetic means \pm SEM $(n=4)$ of the percentage of annexin-Vbinding erythrocytes after a $48 \mathrm{~h}$ treatment with Ringer solution without (white bar) or with (black bars) $10 \mu \mathrm{M}$ patulin in the presence (left bars, Plus Calcium) and absence (right bars, Minus Calcium) of calcium. ${ }^{* * *}(\mathrm{p}<0.001)$ indicates significant difference from the absence of patulin (ANOVA) \#\#\# $(p<0.001)$ indicates significant difference from the respective values in the presence of $\mathrm{Ca}^{2+}$.

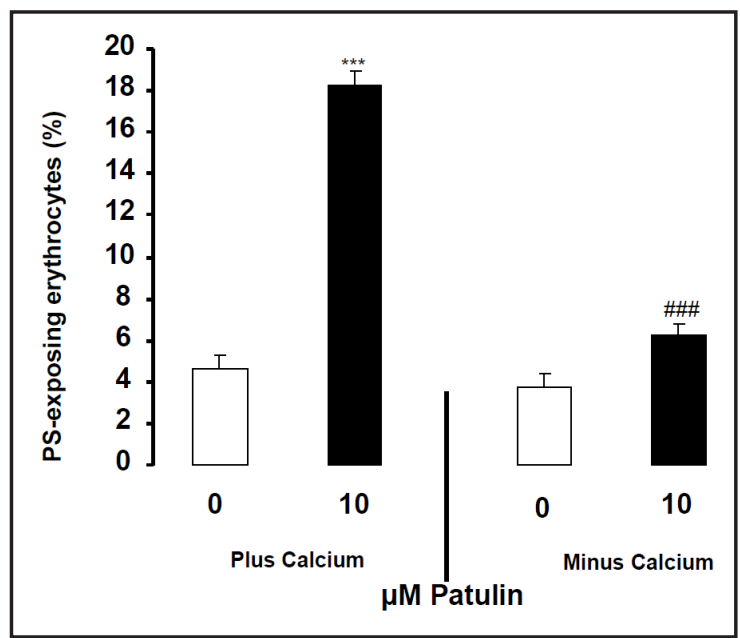

absence of extracellular $\mathrm{Ca}^{2+}$. As illustrated in Fig. 4, the effect of patulin on annexin-V-binding was virtually abolished in the nominal absence of $\mathrm{Ca}^{2+}$. Thus, the effect of patulin was mainly if not exclusively due to $\mathrm{Ca}^{2+}$ entry.

\section{Discussion}

The present study reveals a novel effect of patulin, i.e. its ability to trigger eryptosis, the suicidal death of erythrocytes. Specifically, patulin exposure was followed by erythrocyte shrinkage and erythrocyte membrane scrambling. The concentrations required $(2.5-5 \mu \mathrm{M})$ were similar to those $(2.5-10 \mu \mathrm{M})$ effective in tumor cells [4]. In several countries the tolerance level of patulin contamination amounts to $50 \mu \mathrm{g} / \mathrm{Kg}(320 \mu \mathrm{M})$ [51] Following oral ingestion of radiolabelled patulin, some $36 \%$ of the label appeared in urine pointing to intestinal absorption [52]. Peritoneal administration of $1-3.75 \mathrm{mg} / \mathrm{kg}$ has been reported [53]. From all tissues, erythrocytes displayed the stongest retention of the label [52].

Patulin stimulates cell membrane scrambling mainly by increasing cytosolic $\mathrm{Ca}^{2+}$ activity. Patulin presumably activates the $\mathrm{Ca}^{2+}$ permeable non-selective cation channels in erythrocytes. Those channels have not yet been defined at the molecular level but apparently involve the transient receptor potential channel TRPC6 [8]. Patulin is known to cause oxidative stress $[5,6]$, which in turn is known to activate the $\mathrm{Ca}^{2+}$ permeable unspecific cation channels in erythrocytes [10]. How increase of cytosolic $\mathrm{Ca}^{2+}$ activity triggers cell membrane scrambling is still incompletely understood. The scrambling has been considered to be a function of phospholipid scramblases [54]. $\mathrm{Ca}^{2+}$ has been claimed to stimulate phospholipid scramblase 1 (PLSCR1), a view, however, challenged later [54]. Instead, PLSCR1 may be involved in protein phosphorylation [54]. Thus, the molecular mechanisms underlying $\mathrm{Ca}^{2+}$ sensitive cell membrane scrambling remained incompletely understood.

Activation of the $\mathrm{Ca}^{2+}$ permeable unspecific cation channels most likely accounts in addition for the patulin induced erythrocyte shrinkage. Increase of cytosolic $\mathrm{Ca}^{2+}$ activity results in activation of $\mathrm{Ca}^{2+}$ sensitive $\mathrm{K}^{+}$channels $[11,55]$, which is followed by $\mathrm{K}^{+}$exit, cell membrane hyperpolarisation, $\mathrm{Cl}^{-}$exit and thus cellular loss of $\mathrm{KCl}$ with osmotically obliged water [12]. Closer inspection of Fig. 2A reveals that a subpopulation of erythrocytes underwent dramatic cell shrinkage, whereas the cell volume of another subpopulation remained almost constant. As a matter of fact, erythrocytes are not uniformly sensitive to triggers of eryptosis. The sensitivity increases for instance with erythrocyte age [56].

As apparent from Fig. 4, removal of $\mathrm{Ca}^{2+}$ virtually abolishes the effect of patulin on cell membrane scrampling. Thus, patulin is indeed largely effective by a $\mathrm{Ca}^{2+}$ dependent mechansim. Further mechanisms involved in the stimulation of eryptosis include decline of cytosolic ATP with subsequent activation of protein kinase C [15], activation of caspases [16- 
20], inhibition or lack of AMP activated kinase AMPK [9] or cGMP-dependent protein kinase [21] and activation of Janus-activated kinase JAK3 [22], casein kinase [57, 58], p38 kinase [24], PAK2 kinase [59] as well as sorafenib- [60]) and sunifinib- [61] sensitive kinases.

Consequences of eryptosisinclude derangement of microcirculation, as phosphatidylserine exposing erythrocytes adhere to endothelial CXCL16/SR-PSO of the vascular wall [62], which presumably interferes with blood flow [62-67]. Phosphatidylserine exposure may further foster blood clotting thus predisposing to thrombosis [63, 68, 69].

Eryptosis further leads to the clearance of eryptotic erythrocytes from circulating blood [7]. To the extent that the accelerated loss of erythrocytes is not compensated by a similar increase of erythrocyte formation, enhanced eryptosis leads to anemia [7].

Triggering of apoptosis-like eryptosis may, on the other hand, precede and thus protect against hemolysis, the necrosis like death of erythrocytes. Erythrocytes face the risk to undergo hemolysis following impaired $\mathrm{Na}^{+}$extrusion by the $\mathrm{Na}^{+} / \mathrm{K}^{+}$-ATPase, e.g. under energy depletion, or following enhanced net entry of $\mathrm{Na}^{+}$and $\mathrm{Cl}$, e.g. following leakiness of the cell membrane [70]. In both cases the net gain of $\mathrm{Na}^{+}$and $\mathrm{Cl}^{-}$leads to entry of osmotically obliged water and thus to cell swelling [70]. Excessive erythrocyte swelling may eventually result in cell membrane rupture with release of cellular hemoglobin [70], which may be filtered in renal glomerula and subsequently occlude renal tubules [71]. The activation of $\mathrm{K}^{+}$channels following triggering of eryptosis counteracts cell swelling by hyperpolarization of the cell membrane and thus increase of the driving force for $\mathrm{Cl}^{-}$exit [12]. The exposure of phosphatidylserine at the surface of eryptotic cells leads to subsequent engulfment by phagocytosing cells thus leading to clearance of affected erythrocytes prior to hemolysis [70].

In conclusion, patulin stimulates $\mathrm{Ca}^{2+}$ entry into human erythrocytes with subsequent cell membrane scrambling and cell shrinkage, hallmarks of suicidal death of erythrocytes.

\section{Acknowledgements}

The authors acknowledge the meticulous preparation of the manuscript by Tanja Loch. The study was supported by the Deutsche Forschungsgemeinschaft and Open Access Publishing Fund of Tuebingen University.

\section{References}

1 Ozsoy N, Selmanoglu G, Kockaya EA, Gul N, Cebesoy S: Effect of patulin on the interdigitating dendritic cells (IDCs) of rat thymus. Cell Biochem Funct 2008;26:192-196.

2 Puel O, Galtier P, Oswald IP: Biosynthesis and toxicological effects of patulin. Toxins (Basel) 2010;2:613631.

3 Saxena N, Ansari KM, Kumar R, Dhawan A, Dwivedi PD, Das M: Patulin causes DNA damage leading to cell cycle arrest and apoptosis through modulation of Bax, $\mathrm{p}(53)$ and $\mathrm{p}(21 / \mathrm{WAF} 1)$ proteins in skin of mice. Toxicol Appl Pharmacol 2009;234:192-201.

-4 Fribley AM, Cruz PG, Miller JR, Callaghan MU, Cai P, Narula N, Neubig RR, Showalter HD, Larsen SD, Kirchhoff PD, Larsen MJ, Burr DA, Schultz PJ, Jacobs RR, Tamayo-Castillo G, Ron D, Sherman DH, Kaufman RJ: Complementary cell-based high-throughput screens identify novel modulators of the unfolded protein response. J Biomol Screen 2011;16:825-835.

5 Kwon O, Soung NK, Thimmegowda NR, Jeong SJ, Jang JH, Moon DO, Chung JK, Lee KS, Kwon YT, Erikson RL, Ahn JS, Kim BY: Patulin induces colorectal cancer cells apoptosis through EGR-1 dependent ATF3 upregulation. Cell Signal 2012;24:943-950.

6 Wu TS, Liao YC, Yu FY, Chang CH, Liu BH: Mechanism of patulin-induced apoptosis in human leukemia cells (HL-60). Toxicol Lett 2008;183:105-111. 
7 Lang F, Gulbins E, Lerche H, Huber SM, Kempe DS, Foller M: Eryptosis, a window to systemic disease. Cell Physiol Biochem 2008;22:373-380.

8 Foller M, Kasinathan RS, Koka S, Lang C, Shumilina E, Birnbaumer L, Lang F, Huber SM: TRPC6 contributes to the $\mathrm{Ca}(2+)$ leak of human erythrocytes. Cell Physiol Biochem 2008;21:183-192.

-9 Foller M, Sopjani M, Koka S, Gu S, Mahmud H, Wang K, Floride E, Schleicher E, Schulz E, Munzel T, Lang F: Regulation of erythrocyte survival by AMP-activated protein kinase. FASEB J 2009;23:1072-1080.

10 Brand VB, Sandu CD, Duranton C, Tanneur V, Lang KS, Huber SM, Lang F: Dependence of Plasmodium falciparum in vitro growth on the cation permeability of the human host erythrocyte. Cell Physiol Biochem 2003;13:347-356.

11 Brugnara C, de Franceschi L, Alper SL: Inhibition of $\mathrm{Ca}(2+)$-dependent $\mathrm{K}+$ transport and cell dehydration in sickle erythrocytes by clotrimazole and other imidazole derivatives. J Clin Invest 1993;92:520-526.

12 Lang PA, Kaiser S, Myssina S, Wieder T, Lang F, Huber SM: Role of Ca2+-activated K+ channels in human erythrocyte apoptosis. Am J Physiol Cell Physiol 2003;285:C1553-C1560.

13 Berg CP, Engels IH, Rothbart A, Lauber K, Renz A, Schlosser SF, Schulze-Osthoff K, Wesselborg S: Human mature red blood cells express caspase- 3 and caspase-8, but are devoid of mitochondrial regulators of apoptosis. Cell Death Differ 2001;8:1197-1206.

14 Lang F, Gulbins E, Lang PA, Zappulla D, Foller M: Ceramide in suicidal death of erythrocytes. Cell Physiol Biochem 2010;26:21-28.

15 Klarl BA, Lang PA, Kempe DS, Niemoeller OM, Akel A, Sobiesiak M, Eisele K, Podolski M, Huber SM, Wieder T, Lang F: Protein kinase $\mathrm{C}$ mediates erythrocyte "programmed cell death" following glucose depletion. Am J Physiol Cell Physiol 2006;290:C244-C253.

-16 Bhavsar SK, Bobbala D, Xuan NT, Foller M, Lang F: Stimulation of suicidal erythrocyte death by alpha-lipoic acid. Cell Physiol Biochem 2010;26:859-868.

17 Foller M, Huber SM, Lang F: Erythrocyte programmed cell death. IUBMB Life 2008;60:661-668.

18 Foller M, Mahmud H, Gu S, Wang K, Floride E, Kucherenko Y, Luik S, Laufer S, Lang F: Participation of leukotriene C(4) in the regulation of suicidal erythrocyte death. J Physiol Pharmacol 2009;60:135-143.

19 Lau IP, Chen H, Wang J, Ong HC, Leung KC, Ho HP, Kong SK: In vitro effect of CTAB- and PEG-coated gold nanorods on the induction of eryptosis/erythroptosis in human erythrocytes. Nanotoxicology 2012;6:847856.

20 Maellaro E, Leoncini S, Moretti D, Del Bello B, Tanganelli I, De Felice C, Ciccoli L: Erythrocyte caspase-3 activation and oxidative imbalance in erythrocytes and in plasma of type 2 diabetic patients. Acta Diabetol 2011;(DOI: 10.1007/s00592-011-0274-0).

21 Foller M, Feil S, Ghoreschi K, Koka S, Gerling A, Thunemann M, Hofmann F, Schuler B, Vogel J, Pichler B, Kasinathan RS, Nicolay JP, Huber SM, Lang F, Feil R: Anemia and splenomegaly in cGKI-deficient mice. Proc Natl Acad Sci U S A 2008;105:6771-6776.

22 Bhavsar SK, Gu S, Bobbala D, Lang F: Janus kinase 3 is expressed in erythrocytes, phosphorylated upon energy depletion and involved in the regulation of suicidal erythrocyte death. Cell Physiol Biochem 2011;27:547-556.

-23 Felder KM, Hoelzle K, Ritzmann M, Kilchling T, Schiele D, Heinritzi K, Groebel K, Hoelzle LE: Hemotrophic mycoplasmas induce programmed cell death in red blood cells. Cell Physiol Biochem 2011;27:557-564.

24 Gatidis S, Zelenak C, Fajol A, Lang E, Jilani K, Michael D, Qadri SM, Lang F: p38 MAPK Activation and Function following Osmotic Shock of Erythrocytes. Cell Physiol Biochem 2011;28:1279-1286.

25 Ghashghaeinia M, Toulany M, Saki M, Bobbala D, Fehrenbacher B, Rupec R, Rodemann HP, Ghoreschi K, Rocken M, Schaller M, Lang F, Wieder T: The NFkB Pathway Inhibitors Bay 11-7082 and Parthenolide Induce Programmed Cell Death in Anucleated Erythrocytes. Cell Physiol Biochem 2011;27:45-54.

26 Lang E, Jilani K, Zelenak C, Pasham V, Bobbala D, Qadri SM, Lang F: Stimulation of suicidal erythrocyte death by benzethonium. Cell Physiol Biochem 2011;28:347-354.

27 Nguyen DB, Wagner-Britz L, Maia S, Steffen P, Wagner C, Kaestner L, Bernhardt I: Regulation of phosphatidylserine exposure in red blood cells. Cell Physiol Biochem 2011;28:847-856.

28 Qadri SM, Kucherenko Y, Zelenak C, Jilani K, Lang E, Lang F: Dicoumarol Activates Ca-permeable Cation Channels Triggering Erythrocyte Cell Membrane Scrambling. Cell Physiol Biochem 2011;28:857-864.

29 Qadri SM, Bauer J, Zelenak C, Mahmud H, Kucherenko Y, Lee SH, Ferlinz K, Lang F: Sphingosine but not sphingosine-1-phosphate stimulates suicidal erythrocyte death. Cell Physiol Biochem 2011;28:339-346. 
30 Bhavsar SK, Eberhard M, Bobbala D, Lang F: Monensin induced suicidal erythrocyte death. Cell Physiol Biochem 2010;25:745-752.

31 Braun M, Foller M, Gulbins E, Lang F: Eryptosis triggered by bismuth. Biometals 2009;22:453-460.

32 Eberhard M, Ferlinz K, Alizzi K, Cacciato PM, Faggio C, Foller M, Lang F: FTY720-induced suicidal erythrocyte death. Cell Physiol Biochem 2010;26:761-766.

33 Abed M, Towhid ST, Shaik N, Lang F: Stimulation of suicidal death of erythrocytes by Rifampicin. Toxicology 2012;302:123-128.

34 Lupescu A, Jilani K, Zbidah M, Lang F: Induction of apoptotic erythrocyte death by rotenone. Toxicology 2012;300:132-137.

35 Qadri SM, Kucherenko Y, Lang F: Beauvericin induced erythrocyte cell membrane scrambling. Toxicology 2011;283:24-31.

36 Zbidah M, Lupescu A, Shaik N, Lang F: Gossypol-induced suicidal erythrocyte death. Toxicology 2012;302:101-105.

-37 Calderon-Salinas JV, Munoz-Reyes EG, Guerrero-Romero JF, Rodriguez-Moran M, Bracho-Riquelme RL, Carrera-Gracia MA, Quintanar-Escorza MA: Eryptosis and oxidative damage in type 2 diabetic mellitus patients with chronic kidney disease. Mol Cell Biochem 2011;357:171-179.

-38 Nicolay JP, Schneider J, Niemoeller OM, Artunc F, Portero-Otin M, Haik G, Jr., Thornalley PJ, Schleicher E, Wieder T, Lang F: Stimulation of suicidal erythrocyte death by methylglyoxal. Cell Physiol Biochem 2006;18:223-232.

39 Myssina S, Huber SM, Birka C, Lang PA, Lang KS, Friedrich B, Risler T, Wieder T, Lang F: Inhibition of erythrocyte cation channels by erythropoietin. J Am Soc Nephrol 2003;14:2750-2757.

-40 Lang PA, Beringer O, Nicolay JP, Amon O, Kempe DS, Hermle T, Attanasio P, Akel A, Schafer R, Friedrich B, Risler T, Baur M, Olbricht CJ, Zimmerhackl LB, Zipfel PF, Wieder T, Lang F: Suicidal death of erythrocytes in recurrent hemolytic uremic syndrome. J Mol Med 2006;84:378-388.

41 Kempe DS, Akel A, Lang PA, Hermle T, Biswas R, Muresanu J, Friedrich B, Dreischer P, Wolz C, Schumacher U, Peschel A, Gotz F, Doring G, Wieder T, Gulbins E, Lang F: Suicidal erythrocyte death in sepsis. J Mol Med 2007;85:273-281.

42 Lang PA, Kasinathan RS, Brand VB, Duranton C, Lang C, Koka S, Shumilina E, Kempe DS, Tanneur V, Akel A, Lang KS, Foller M, Kun JF, Kremsner PG, Wesselborg S, Laufer S, Clemen CS, Herr C, Noegel AA, Wieder T, Gulbins E, Lang F, Huber SM: Accelerated clearance of Plasmodium-infected erythrocytes in sickle cell trait and annexin-A7 deficiency. Cell Physiol Biochem 2009;24:415-428.

43 Siraskar B, Ballal A, Bobbala D, Foller M, Lang F: Effect of amphotericin B on parasitemia and survival of plasmodium berghei-infected mice. Cell Physiol Biochem 2010;26:347-354.

44 Bobbala D, Alesutan I, Foller M, Huber SM, Lang F: Effect of anandamide in Plasmodium Berghei-infected mice. Cell Physiol Biochem 2010;26:355-362.

45 Foller M, Bobbala D, Koka S, Huber SM, Gulbins E, Lang F: Suicide for survival--death of infected erythrocytes as a host mechanism to survive malaria. Cell Physiol Biochem 2009;24:133-140.

46 Koka S, Bobbala D, Lang C, Boini KM, Huber SM, Lang F: Influence of paclitaxel on parasitemia and survival of Plasmodium berghei infected mice. Cell Physiol Biochem 2009;23:191-198.

-47 Lang PA, Schenck M, Nicolay JP, Becker JU, Kempe DS, Lupescu A, Koka S, Eisele K, Klarl BA, Rubben H, Schmid KW, Mann K, Hildenbrand S, Hefter H, Huber SM, Wieder T, Erhardt A, Haussinger D, Gulbins E, Lang F: Liver cell death and anemia in Wilson disease involve acid sphingomyelinase and ceramide. Nat Med 2007;13:164-170.

48 Kempe DS, Lang PA, Duranton C, Akel A, Lang KS, Huber SM, Wieder T, Lang F: Enhanced programmed cell death of iron-deficient erythrocytes. FASEB J 2006;20:368-370.

49 Birka C, Lang PA, Kempe DS, Hoefling L, Tanneur V, Duranton C, Nammi S, Henke G, Myssina S, Krikov M, Huber SM, Wieder T, Lang F: Enhanced susceptibility to erythrocyte "apoptosis" following phosphate depletion. Pflugers Arch 2004;448:471-477.

-50 Zappulla D: Environmental stress, erythrocyte dysfunctions, inflammation, and the metabolic syndrome: adaptations to CO2 increases? J Cardiometab Syndr 2008;3:30-34.

51 Arafat W, Musa MN: Patulin-induced inhibition of protein synthesis in hepatoma tissue culture. Res Commun Mol Pathol Pharmacol 1995;87:177-186. 
Lupescu/Jilani/Zbidah/Lang: Patulin-Induced Eryptosis

52 Dailey RE, Blaschka AM, Brouwer EA: Absorption, distribution, and excretion of [14C]patulin by rats. J Toxicol Environ Health 1977;3:479-489.

-53 de Melo FT, de Oliveira IM, Greggio S, DaCosta JC, Guecheva TN, Saffi J, Henriques JA, Rosa RM: DNA damage in organs of mice treated acutely with patulin, a known mycotoxin. Food Chem Toxicol 2012;50:3548-3555.

54 Sahu SK, Gummadi SN, Manoj N, Aradhyam GK: Phospholipid scramblases: an overview. Arch Biochem Biophys 2007;462:103-114.

-55 Bookchin RM, Ortiz OE, Lew VL: Activation of calcium-dependent potassium channels in deoxygenated sickled red cells. Prog Clin Biol Res 1987;240:193-200.

-56 Ghashghaeinia M, Cluitmans JC, Akel A, Dreischer P, Toulany M, Koberle M, Skabytska Y, Saki M, Biedermann T, Duszenko M, Lang F, Wieder T, Bosman GJ: The impact of erythrocyte age on eryptosis. Br J Haematol 2012;157:606-614.

57 Kucherenko Y, Zelenak C, Eberhard M, Qadri SM, Lang F: Effect of casein kinase 1alpha activator pyrvinium pamoate on erythrocyte ion channels. Cell Physiol Biochem 2012;30:407-417.

-58 Zelenak C, Eberhard M, Jilani K, Qadri SM, Macek B, Lang F: Protein kinase CK1alpha regulates erythrocyte survival. Cell Physiol Biochem 2012;29:171-180.

59 Zelenak C, Foller M, Velic A, Krug K, Qadri SM, Viollet B, Lang F, Macek B: Proteome analysis of erythrocytes lacking AMP-activated protein kinase reveals a role of PAK2 kinase in eryptosis. J Proteome Res 2011;10:1690-1697.

60 Lupescu A, Shaik N, Jilani K, Zelenak C, Lang E, Pasham V, Zbidah M, Plate A, Bitzer M, Foller M, Qadri SM, Lang F: Enhanced erythrocyte membrane exposure of phosphatidylserine following sorafenib treatment: an in vivo and in vitro study. Cell Physiol Biochem 2012;30:876-888.

61 Shaik N, Lupescu A, Lang F: Sunitinib-sensitive suicidal erythrocyte death. Cell Physiol Biochem 2012;30:512-522.

-62 Borst O, Abed M, Alesutan I, Towhid ST, Qadri SM, Foller M, Gawaz M, Lang F: Dynamic adhesion of eryptotic erythrocytes to endothelial cells via CXCL16/SR-PSOX. Am J Physiol Cell Physiol 2012;302:C644-C651.

63 Andrews DA, Low PS: Role of red blood cells in thrombosis. Curr Opin Hematol 1999;6:76-82.

64 Closse C, Dachary-Prigent J, Boisseau MR: Phosphatidylserine-related adhesion of human erythrocytes to vascular endothelium. Br J Haematol 1999;107:300-302.

65 Gallagher PG, Chang SH, Rettig MP, Neely JE, Hillery CA, Smith BD, Low PS: Altered erythrocyte endothelial adherence and membrane phospholipid asymmetry in hereditary hydrocytosis. Blood 2003;101:46254627.

66 Pandolfi A, Di Pietro N, Sirolli V, Giardinelli A, Di Silvestre S, Amoroso L, Di Tomo P, Capani F, Consoli A, Bonomini M: Mechanisms of uremic erythrocyte-induced adhesion of human monocytes to cultured endothelial cells. J Cell Physiol 2007;213:699-709.

67 Wood BL, Gibson DF, Tait JF: Increased erythrocyte phosphatidylserine exposure in sickle cell disease: flowcytometric measurement and clinical associations. Blood 1996;88:1873-1880.

68 Chung SM, Bae ON, Lim KM, Noh JY, Lee MY, Jung YS, Chung JH: Lysophosphatidic acid induces thrombogenic activity through phosphatidylserine exposure and procoagulant microvesicle generation in human erythrocytes. Arterioscler Thromb Vasc Biol 2007;27:414-421.

69 Zwaal RF, Comfurius P, Bevers EM: Surface exposure of phosphatidylserine in pathological cells. Cell Mol Life Sci 2005;62:971-988.

70 Lang E, Qadri SM, Lang F: Killing me softly - suicidal erythrocyte death. Int J Biochem Cell Biol 2012;44:1236-1243.

71 Harrison HE, Bunting H, Ordway NK, Albrink WS: The Pathogenesis of the Renal Injury Produced in the Dog by Hemoglobin or Methemoglobin. J Exp Med 1947;86:339-356. 